\title{
Reparasie, die onbetaalde rekening van die Waarheids- en Versoeningsproses
}

\author{
P G J Meiring \\ (Universiteit van Pretoria)
}

\begin{abstract}
Reparations, the unpaid account of the Truth and Reconciliation process

The author contends that the final question about the contribution of the South African Truth and Reconciliation Commssion will not be whether the Human Rights Violations Committee or even the Amnesty Committee were successful in their respective tasks of collecting data, as well as holding numerous victims' and amnesty hearings throughout the country, but concerns the question of reparation to the victims of apartheid. Raising his concern about the fact that government was slow to act upon the TRC's reparation proposals, he underlines the reasons why proper reparation was of supreme importance to the victims as well as to the nation. After discussing the five categories of reparation proposals, the author suggests a number of areas where the faith communities in the country have a unique and significant contribution to make.
\end{abstract}

\section{1 'N ONBETAALDE REKENING}

"Dis nou reeds vier jaar gelede dat, op 15 April 1996, die eerste verhoor van die Waarheids- en Versoeningskommissie in die OosKaap plaasgevind het. Dis reeds agtien maande gelede dat die WVK . sy amptelike verslag aan president Nelson Mandela voorgelê het - en nog het die slagoffers, die mense wat veronderstel was om deur die proses gehelp te word, nie " $n$ enkele woord van die regering gehoor oor die reparasie wat hulle sou ontvang nie".

Dit was tydens die amptelike bekendstelling van 'n kompakskyf-reeks wat die Suid-Afrikaanse Uitsaaikorporasie (SABC) oor die werk van die WVK saamgestel het, dat een van die kommissarisse van die WVK, Yasmin Sooka, haar ernstige oproep gedoen het. Oor die nuusdienste van die SABC is haar stem en haar beeld uitgesaai: "The silence is deafening. Ngawna ya salleng oshwela tharing!" (Sooka 2000:1).

Sooka was maar één stem in " $n$ koor wat die afgelope maande dieselfde vraag gevra het. Koerantredakteurs, politieke kommentators, kerkleiers, bo alles apartheidslagoffers wat destyds voor die WVK verskyn 
het, het almal die kreet opgeneem: waarom neem die uitvoering van die WVK se reparasievoorstelle so lank?

\section{DIE DERDE BEEN VAN DIE WVK-PROSES}

Toe mnr Dullah Omar, die destydse Minister van Justisie, in Julie 1995 die Wet op Nasionale Eenheid en Versoening voor die Suid-Afrikaanse parlement gelê het, het hy die doelwitte van die WVK duidelik uitgespel:

"I have the privilege and responsibility to introduce a Bill that provides a pathway, a stepping stone, towards the historic bridge of which the Constitution speaks whereby our society can leave behind the past of a deeply devided society, characterised by strife, conflict, untold suffering and injustice, and commence the journey towards a future founded on the recognition of human rights, democracy and peaceful co-existence, and development opportunities for all South Africans irrespective of colour, race, class, belief, or sex" (TRC Report, Vol I, 1998:48).

Om hierdie historiese brug te bou, moes ' $n$ Waarheids- en Versoeningskommissie aangestel word, nie alleen om ' $\mathrm{n}$ verslag oor wat alles in die resente verlede in ons land gebeur het voor te berei nie, maar om ook aan slagoffers én oortreders, aan die hele bevolking van die land, die geleentheid te gee om vorentoe, ' $n$ nuwe toekoms in, te beweeg. Drie komitees sou as instrumente dien om dit te probeer vermag: ' $n$ Mensregteskendingskomitee, 'n Amnestiekomitee en ' $n$ Reparasie- en Rehabilitasie-komitee.

In Januarie 1996 het die WVK met sy proses begin. Dit was ' $n$ duur proses, nie net in terme van geld nie, maar veral in terme van mannekrag en tyd. Dit was in "n goot mate ook "n pynlike proses. Onder leiding van aartsbiskop Desmond Tutu het die hele Suid-Afrikaanse samelewing as't ware op ' $n$ lang tog vertrek, ' $n$ trek deur die verlede en die hede - na die toekoms van Suid-Afrika. Suid-Afrika sou nooit weer dieselfde wees nie, was die algemene gevoel toe die WVK uiteindelik in Oktober 1998 sy vyf-volume verslag aan President Mandela oorhandig het - en met reg. Want die voetspore van die duisende slagoffers én oortreders - van die hele Suid-Afrikaanse gemeenskap wat hulle op hul tog vergesel het - sal nog vir baie jare oor die landskap lê.

Die Mensregteskendingskomitee het hard gewerk. Gedurende die WVK-jare is die getuienis van 21400 slagoffers versamel, 27000 name van slagoffers geregistreer, is 140 verhore waartydens honderde slagoffers in die openbaar getuienis afgelê het in talle stede en dorpe dwarsoor die land gehou, waartydens groot getalle slagoffers hul verhale vertel het. Bo en behalwe die menseregteskendingsverhore is spesiale sittings gehou waar politieke partye, sakelui, akademici, medici, gevangenispersoneel, media- 
mense, regsgeleerdes, uiteindelik ook die leiers van al die groot geloofsgemeenskappe in die land, hul perspektiewe op die verlede kon stel.

Terselfdertyd het die Amnestiekomitee ook met sy werksaamhede voortgegaan. In plaas daarvan dat - soos aanvanklik verwag is - ' $n$ paar honderd oortreders by die Amnestiekommissie sou aanmeld, het nie minder nie as 7124 persone om amnestie aansoek gedoen. Ten spyte van die feit dat daar met verloop van tyd nog aanstellings op die Amnestiekomitee gemaak is om die druk te verlig, kon die Amnestiekomitee toe die afsluitingsdatum vir die WVK aanbreek, nie sy werk afhandel nie. Die komitee kon slegs ' $\mathrm{n}$ voorlopige verslag voorlê. Die verwagting is dat die kommissie eers teen die einde van 2000 sy finale voorlegging sal kan maak. Die berigte oor die amnestieverhore, oor watter oortreders inderdaad amnestie ontvang het en watter nie, het die afgelope jare feitlik weekliks in die koerante verskyn, en dikwels tot hewige debatte aanleiding gegee.

Intussen het die derde been van die WVK-proses, die Reparasie- en Rehabilitasiekommissie, ook met sy werk voortgegaan. Die Reparasie- en Rehabilitasiekomitee het ' $n$ dubbele verantwoordelikheid gehad. Eerstens moes die komitee so noukeurig moontlik nagaan wat die behoeftes van die duisende slagoffers was wat hul tot die WVK gewend het, onder watter omstandighede hulle geleef het en wat die mees algemene probleme was waarmee hulle geworstel het. Tweedens moes die komitee - in samewerking met alle moontlike rolspelers in die regering en die breë samelewing - voorstelle formuleer oor hoe die regering hierdie behoeftes kon hanteer. Werkswinkels is in verskeie sentra in die land gehou. By hierdie geleenthede was talle kerke en para-kerklike organisasies betrokke. Die priesters en predikante, veral die vroue, het nie net die behoeftes van hul lidmate verstaan nie, maar met entoesiasme aan die formulering van die reparasie-en rehabilitasievoorstelle meegewerk. By talle sinodes en ekumeniese byeenkomste - veral tydens konferensies van die S A Raad van Kerke, die Suid-Afrikaanse Kerkleiersforum en The Evangelical Alliance of Southern Africa - is baie aandag aan reparasie en die rehabilitasie van slagoffers gegee.

\section{WAAROM SO BELANGRIK?}

Vroeg al in die WVK-proses is besef dat reparasie van die allergrootste belang is. Verskeie redes is aangegee:

3.1 Eerstens sou reparasie as erkenning dien van die nood en die lyding wat duisende Suid-Afrikaners gedurende die apartheidsjare in Suid-Afrika gely het. Hoe groot en wydverspreid die nood was, het pas gedurende die menseregteskendingsverhore duidelik geword. Mans, vroue en kinders, slagoffers vanuit elke bevolkingsgroep in die land, het ' $n$ duur prys betaal en daaraan moes openbare erkenning gegee word, nie net deur die 
geleenthede te skep waartydens slagoffers hul verhale kon vertel nie, maar deur toepaslike reparasie aan te bied. Deur dit te doen, het Desmond Tutu na afloop van die WVK geskryf, wou die Suid-Afrikaanse samelewing aan die slagoffers en hul gesinne sê: Ons is jammer oor wat met julle gebeur het.

"We acknowledge that you suffered a gross violation of your rights. Nothing can ever replace your loved one. But as a nation we are saying, we are sorry, we have opened the wounds of your suffering and sought to cleanse them; this reparation is a balm, an ointment, being poured over the wounds to assist in their healing" (1999:57).

3.2 Tweedens het die werklike behoeftes van slagoffers, die haglike omstandighede waarin talle mans en vroue van alle ouderdomme verkeer het - mense wat na al die jare nog die letsels van fisiese of psigiese marteling gedra het - rehabilitasie en reparasie dringend nodig gemaak. By feitlik elke menseregteskendingsverhoor en sitting van die amnestiekomitee het slagoffers op krukke of in rystoele aangemeld. Baie van hulle was jare reeds werkloos en het in haglike omstandighede sonder vaste heenkome ' $n$ bestaan probeer makk.

3.3 Die derde rede vir reparasie het op ' $n$ nog dieper vlak gelê. Reeds gedurende die eerste maande van die WVK het ' $n$ aantal vooraan-staande slagofferfamilies ernstige besware teen die Waarheids- en Versoeningsproses gelug. In die Oos-Kaap het die families van die bekende aktiviste wat gedurende die apartheidsjare vermoor is - Steve Biko, Mathew Goniwe, en ander - die werk van die WVK in die hof teengestaan, eers in die Hooggeregshof, later selfs in die Konstitusionele Hof. Die proses was volgens hulle oortuiging onbil-lik en oortredervriendelik ("perpetrator friendly"). Oortreders wat om amnestie aansoek gedoen het en aan wie dit toegestaan word - het letterlik alles ontvang: volledige kwytskelling van die misdade wat hulle gepleeg het. Dit sou nie eers saak maak by hoeveel moorde hulle betrokke was nie, as hulle die vereistes van die wet nagekom het - as hulle ' $n$ volledige verklaring gemaak het en as hul kon aantoon dat hulle ' $n$ politieke of militêre motief vir hul wandade gehad het - was hulle so vry soos voëls wat uit ' $n$ kou gelaat word. Daar sou geen verdere strafregtelike of selfs siviele stappe teen hulle geneem kon word nie. En die slagoffers? Wat was daar vir hulle in die proses? So goed as niks, het die Goniwe en Biko-gesinne geargu-menteer. Die familielede sou nie eers die moordenaars om skadever-goeding kon dagvaar nie. Die WVK "het die brood uit die monde van die weduwees en wese geneem" (Meiring 1999:19; Krog 1999:14-31).

"Was die WVK-proses, bo alles die amnestie-proses, eties aanvaarbaar?" was die vraag op talle lippe. In sy uitspraak in die 
Konstitusionele Hof het regter Mahomed verklaar dat die wetgewing en die proses wel aanvaarbaar is, veral omdat daar nie net aan die behoeftes van oortreders aandag gegee word nie, maar ook aan dié van die slagoffers. Die proses was ten diepste slagoffervriendelik ("victim friendly"). Hulle sou behoorlike reparasie en rehabilitasie ontvang. In die finale verslag van die WVK is dit duidelik gestel dat reparasie ' $n$ sine qua non was, dat die sukses van die WVK daarvan afhanklik was:

"Without adequate reparation and rehabilitation measures, there can be no healing and reconciliation, either at an indivi-dual or community level... In addition... reparation is essen-tial to counterbalance amnesty. The granting of amnesty denies victims the right to institute civil claims against perpetrators. The government should thus accept responsibility for reparation" (Tutu 1999:55; vgl verder MullerFahrenholz 1997:85-100).

3.4 ' $\mathrm{n}$ Vierde argument was die feit dat talle internasionale verklarings die belangrikheid - meer nog, die morele noodsaaklikheid - van voldoende reparasie vir slagoffers beklemtoon het. Die Universele Verklaring van Menseregte, die Internasionale Handves oor Burgerlike en Politieke Regte, die Handves teen Marteling en Ander Wrede, Onmenslike of Vernederende Behandeling of Straf - almal dokumente wat deur die Suid-Afrikaanse regering onderteken is - sowel as die Inter-Amerikaanse Konvensie oor Menseregte, bevat almal sterk verklarings oor die reparasieplig van regerings. In die finale verslag van die WVK is lang aanhalings uit hierdie dokumente voorgelê (TRC Report, Vol V, 1998:172-175).

Met soveel op die spel is daar lank en ernstig oor die reparasievoorstelle van die WVK gedink en gedebatteer. Verkeie werkswinkels is met kerkgroepe, nie-regeringsorganisa-sies, akademici en staatsamptenare - ook met nasionale en provinsiale kabinetslede - oor die saak gehou. Algaande het dit duidelik geword dat daar vyf tipiese behoeftes onder die slagoffers en hul gesinne bestaan het, behoeftes waarvoor daar in die WVK-verslag voorsiening gemaak sou moes word.

4.1 Eerstens moes daar aan die mees dringende behoeftes van die slagoffers wat oud of siek was, of wat in haglike omstandighede verkeer het, aandag gegee word. " $n$ Skema moes in werking gestel word waardeur dringende interimhulp ("urgent interim relief") aan hierdie ongelukkiges gebied word. Reeds tydens die WVK-proses is daar op beperkte skaal uitbetalings gemak uit fondse wat vanuit die buiteland verkry is. Maar, 
was die oordeel van die WVK, gedurende die eerste maande ná die afsluiting van die WVK - terwyl die repa-rasiemasjinerie aan die gang gesit word - sal interimhulp nog altyd nodig wees. Klein bedrae geld, van tussen R2 000 en R5 000 per gesin, is voorgestel (TRC Report Vol V, 1998:180-184).

4.2 Tweedens het die WVK voorgestel dat daar aan elke slagoffer - of indien die slagoffer gesterf het, aan die oorlewende gesinslede - ' $n$ bedrag geld uitbetaal moes word ("individual reparation grant"). Oor dié wysheid en die uitvoerbaarheid van die voorstel is lank gekonfe-reer, maar uiteindelik het die WVK dit as sy vaste oortuiging gestel: ter wille van die nood van die slagoffers én as erkenning van die lyding wat hulle deurgemaak het, moes die uitbetalings gemaak word. Meer nog, het die rapport gelui, die regering het die dure plig om die ruim amnestievoordele wat aan oortreders gebied is, met ewe ruim reparasievoordele te balanseer.

Tydens verskeie werkswinkels wat oor die saak gehou is waaraan verteenwoordigers van die S A Raad van Kerke, die Katolieke biskoppekonferensie en afgevaardigdes van talle kerkgenootskappe in die land deelgeneem het, is baie vrae gevra: Hoe bepaal jy die prys van lyding en dood? Hoeveel geld behoort 'n vrou wat eenmaal verkrag is te ontvang? En tweemaal? En ontvoering? En marteling? En moord? Hoeveel rand moet aan ' $n$ gesin wat hul vader - die broodwinner van die gesin - verloor het, uitbetaal word? Baie gou het die Reparasie en Rehabilitasiekomitee besef dat dié weg nie opgegaan kan word nie, dat elke slagoffer - wat ookal met hom of haar gebeur het - eenvoudig dieselfde bedrag moes ontvang.

Oor die vraag hoe groot die bedrag moes wees, is ook lank geworstel. Verskillende opsies is oorweeg. In Suid-Afrika, in 1997, was die "broodlyn" vir "n gesin R15 600 per jaar. Sou dit as basis vir vergoeding kon dien? Die konsensus was dat dit nie voldoende sou wees nie. "Wat sê ons daarmee?", het een van die WVK-kommissa-risse gevra, "Dat ons die slagoffers wil help om net-net liggaam en siel aanmekaar te hou?" 'n Meer aanvaarbare voorstel was om die gemiddelde jaarlikse inkomste van ' $n$ Suid-Afrikaanse gesin, dit wil sê R21 700, as basis vir berekening te neem. Die boodskap wat so aan slagoffers gestuur sou word was: "Ons wil julle graag in staat stel om vir die volgende paar jaar "n normale lewe te lei" (Meiring 1999:253). Uiteindelik is voorgestel dat aan elke slag-offer of slag-offergesin ' $n$ jaarlikse bedrag wat wissel tussen R17 000 en R23 000 uit te betaal. Slagoffers wat in veraf plattelandse gebiede woon, vér van mediese en ander geriewe, asook dié met besonder baie afhank-likes sou méér moes ontvang as stedelinge of slagoffers met kleiner gesinne. Die WVK het verder voorgestel dat die bedrag jaarliks, ses jaar lank, oorbetaal moes word. As uitbetalings aan ongeveer 20000 slagoffers gemaak moes word, is bereken, sou dit die regering R55 miljoen per jaar kos; R3 miljard 
oor die loop van ses jaar (TRC Report, Vol V, 1998:184-187; Orr 2000:244-249).

Die bedrag het talle wenkbroue laat lig. Kon die land dit bekostig? Wendy Orr, ondervoorsitter van die Reparasie- en Rehabi-litasiekomitee, het tydens ' $n$ perskonferensie (23 Oktober 1997) waartydens die reparasievoorstelle aan die media bekendgestel is, verduidelik:

"Dit (die bedrag) is nie so onredelik baie nie: dit beloop 0,25 persent van die regering se nasionale begroting. En dit het die regering tog seker vir die slagoffers oor? En dink ' $n$ bietjie verder: as ons nie op dié wyse vir die slagoffers voorsiening mak nie en die 22000 slagoffers met regsgedinge (teen die regering) sou kom, hoeveel sou dit nie die land gekos het nie? Oneindig méér" (Meiring 1999:253).

Om die uitbetalings te administreer, het die WVK voorgestel, moes ' $n$ spesiale fonds in die kantoor van die president ("President's Fund") in die lewe geroep word. Die verwagting is geuiter dat alhoe-wel die hoofverantwoordelikheid op die regering self sou rus om die nodige fondse te voorsien, ruim bydraes van die publiek, van oorsese donateurs, asook van die regerings van baie lande wat hulle met die proses vereenselwig het - en reeds hul bereidwilligheid in die verband verklaar het - die fonds sou versterk. Die moontlikheid is ook voorgehou dat oortreders wat amnestie ontvang het, die geleent-heid behoort te kry om ' $\mathrm{n}$ eie bydrae te lewer. Watter voorbeeld en getuienis sou dit nie wees nie? (TRC Report V, 1998:185-186).

4.3 Die derde groep voorstelle het met simboliese reparasie ("symbolic reparation") te make gehad. Talle slagoffers het tydens sittings van die menseregteskendingskomitee en die amnestiekomitee die wens uitgespreek dat een of ander simboliese handeling uitgevoer moes word: die herbegrafnis van geliefdes, die oprigting van grafstene, ensovoorts. Ander het weer gevra dat geliefdes wat jare gelede reeds verdwyn het, dood verklaar moes word sodat boedels afgehandel en wetlike verpligtinge nagekom kon word. Vir baie ander was die skoonvee van die kriminele rekords van mense wat as gevolg van die apartheidswette veroordeel is, van groot belang. Ander simboliese handelinge waarvan hele gemeenskappe uiteindelik die land as geheel - voordeel sou kon trek, was die herbenaming van strate, skole, hospitale en woongebiede om die helde van die stryd te herdenk, asook die oprigting van gedenktekens en monumente in verskillende dele van die land. Ook die reël van spesiale seremonies en versoeningsgeleenthede, bo al die afkondiging van ' $n$ nasionale versoeningsdag, is in die vooruitsig gestel. In sy finale verslag het die WVK ' $n$ spesiale oproep op die Christelike kerke sowel as die ander 
geloofsgemeen-skappe in Suid-Afrika gedoen om hier die voortou te neem (TRC Report, Vol V, 1998:316-318).

4.4 ' $n$ Vierde kategorie reparasievoorstelle het die verbetering van gemeenskapsdienste ten doel gehad. Tydens feitlik alle WVK-verhore is die behoefte aan beter en meer toeganklike hospitaal- en kliniekdienste, die oprigting van skole en ander onderwysinrigtings in bepaalde gemeenskappe, die versnelling van behuisingsprojekte, ensovoorts, aan die orde gestel. Hierdie behoeftes is met verteen-woordigers van die verskillende provinsiale regerings bespreek. Uiteindelik is ' $n$ reeks gesamentlike voorstelle geformuleer waarvan nie net die slagoffers nie, maar ook die wyer gemeenskap voordeel sou kon trek (TRC Report, Vol V, 190-193).

4.5 Die laaste reeks voorstelle het oor institusionele reparasie gehandel. Deel van die opdrag van die WVK was om uit die gegewens wat versamel is, uit die kennis en insig wat gedurende die proses verwerf is, voorstelle te formuleer oor hoe die lesse van die geskiedenis geleer kan word, hoe die vergrype van die verlede in die toekoms voorkom kan word. Vir talle staatsdepartemente en nie-regeringsor-ganisasies, vir onderwysinstellings, die media, die besigheidsektor, die regsberoep, asook vir die geloofsgemeenskappe in die land, was daar inderdaad heelwat lesse te leer - en suggesties om op te volg (TRC Report, Vol V, 194-195).

\section{TELEURSTELLING}

Toe die WVK sy finale verslag op 29 Oktober 1998 aan Nelson Mandela oorhandig het, was die verwagtinge hoog. Só ook die spanning. Want terwyl die president en van sy senior-kollegas in Pretoria aangekom het om die verslag in ontvangs te neem, het Thabo Mbeki in die geselskap van ander senior ANC-amptenare hul tot die Kaapse Hooggeregshof gewend om - ter elfder ure - om die publikasie van die verslag te verbied. Die rede daarvoor was dat die verslag na die oordeel van die ANC die rol wat die vryheidsvegters in die verlede gespeel het, "gekriminaliseer" het. Oortreders uit die kringe van die ANC, die PAC en AZAPO - die wat téén apartheid geveg het - moes op ' $n$ ander wyse as oortreders vanuit die kring van die voormalige regering en die veiligheidsmagte - diegene wat geveg het om die bose apartheidsbeleid staande te hou - beoordecl gewees het. En die WVK het alle oortreders oor dieselfde kam geskeer! Die hof in Kaapstad het vroeg die oggend van 29 Oktober ten gunste van die WVK besluit. Die seremonie in Pretoria kon voortgaan. Aartsbiskop Tutu het die verslag oorhandig - en president Mandela het dit met " $n$ wye glimlag ontvang. "Ek aanvaar die verslag", het die president gesê, "soos wat dit is, met al sy onvolmaakthede as dié hulp wat die WVK ons bied om by versoening en 
nasiebou uit te kom... Kom ons stap saam na die toekoms. Uiteindelik is ons vry, kan ons met verantwoordelikheid ons roeping aanvaar" (Meiring, 1999:377).

Vir Tutu en sy kollegas was deel van die verantwoordelikheid waarvan president Mandela gepraat het, die verantwoordelikheid om die reparasievoorstelle te ontvang en te implementeer. Die voorstelle was immers lank reeds aan die regering bekend. Gedurende die laaste maande van die WVK is talle werkswinkels gehou waarby regeringsamptenare betrokke was, waartydens die spesifieke finansiële implikasies van die voorstelle met die ministers van Justisie en Finansies deurgepraat is.

Die teleurstelling was groot toe die WVK-verslag enkele weke later voor die parlement gelê is. Die entoesiasme van die ANC-regering was louwarm. Was dit omdat die WVK op ANC-tone getrap het? Daar was baie wat van dié mening toegedaan was. Die destydse Minister van Justisie, Dullah Omar, het egter verklaar dat die regering as gevolg van finansiële oorwegings nie anders kon as om hulle langsaam te haas nie. Sekere sake soos simboliese reparasie, gemeenskapsinisiatiewe, en institusionele reparasie was reeds op die program, het hy gesê. Maar wat uitbetalings aan slagoffers betref, sou daar eers gewag moes word (Tutu 1999:59 v).

Die wagtyd het lank geword. Slagoffers oor die hele land - veral slagofferondersteunersgroepe soos die Khulumani-groep in Gauteng - het hul frustrasie begin lug. Die Amnestiekomitee se werk het fluks gevorder. Weekliks is in die koerante berig dat oortreders amnestic ontvang het. Maar wat van die slagoffers - wat van die belofte van die "balans" van reparasie vir slagoffers? Agtien maande ná die verskyning van die verslag, gedurende die eerste maande van 2000 het oud-WVK-lede, slagoffers én die pers hande gevat. Aartsbiskop Tutu en Hlengiwe Mkhize, voorsitter van die Reparasie- en Rehabilitasiekomitee, het gedurende Februarie met ' $n$ sterkbewoorde verklaring gekom. Hulle was diep onsteld, het hulle gesê, omdat die regering "gerieflikheidshalwe" van die betaling van vergoeding en van die ander reparasie-voorstelle probeer vergeet (The Star, 20 May 2000:13; Beeld, 6 Jun 2000:2). So ook Yasmin Sooka, wat tydens die menseregteskendingsverhore ' $\mathrm{n}$ besondere rol gespeel het. "Die regering speel met vuur", het sy betoog. "Leer ons dan nie die les van Zimbabwe nie?", het sy met verwysing na die vlaag plaasbesettings deur oorlogsveterane in ons buurland gevra. Beloftes wat gemaak word en nie gehou word nie, is gevaarlik! "In the twenty years that have gone by, no effort was made by the government (of Zimbabwe) to deal with the war veterans and now that unfinished business may destroy the present" (Sooka 2000:3).

Kort daarna het Dumisa Ntsebeza, voormalige hoof van ondersoeke van die WVK wat intussen as waamemende regter in die Amnestiekomitee diens begin doen het, hom by sy kollegas aangesluit. Hy word oorval deur slagoffers, het Ntsebeza in Kaapstad verklaar. Hulle wil weet wanneer hul hul reparasie-uitbetalings gaan ontvang. "Vir baie van die mense word ' $n$ 
geding in die konstitusionele hof waarin die grondwetlikheid van die WVK-proses bevraagteken word, die enigste uitweg om vergoeding te bekom". Niemand het dit nog gedoen nie, maar vir slagoffers wat as gevolg van die WVK-proses die reg om siviele eise in te stel verloor het, kan dit nou die aangewese weg wees. "Intussen voel die slagoffers van apartheid dat die regering hulle verraai" (Beeld, 6 Jun 2000:2).

Die regering is besig om sy beleid oor reparasie te finaliseer, het Paul Seretse, woordvoerder van die Ministerie van Justisie, op die kritiek geantwoord. ' $n$ Interdepartementele komitee van direkteurs-generaal van Justisie, Welsyn, Behuising en Onderwys is besig om ' $n$ omvattende verslag voor te berei. Voordat dit nie afgehandel is nie kan die minister van Finansies, Trevor Manuel, geen uitbetalings sanksioneer nie, het Seretse verduidelik. Die slagoffergemeenskap, WVK-lede, ook die pers, was nie oortuig nie. "Die WVK se pleidooi... verdien ernstige en dringende aandag", het die redakteur van die Johannesburgse dagblad Beeld in " $n$ inleidingsartikel geskryf. "Dit is belangrik dat die slagoffers van die apartheidsera hul waardigheid herwin, pleks daarvan dat hul ervaring van die nuwe samelewing dieselfde is as wat hulle in die oue beleef het" (Beeld, 6 Junie 2000, 8).

\section{DIE BYDRAE VAN DIE KERKE IN SUID-AFRIKA}

\subsection{Inleiding}

Sou die kerklike gemeenskap in Suid-Afrika ' $n$ eie bydrae kon maak om die reparasieproses weer op gang te kry? Vóór die WVK met sy werk begin het, was die kerke - soos ook verteenwoordigers van die ander geloofsgemeenskappe in die land - diep by die proses betrokke, nie net deur die beginsels van die Waarheids- en Versoeningsproses te debatteer en te help ontwikkel nie, maar ook deur die eerste dokumente wat tot die wetgewing aanleiding sou gee, te help skryf. Gedurende die WVK-jare het die kerke selfs nog ' $n$ nog groter bydrae gelewer deur inligting te versprei, mense aan te moedig om deel te neem en veral deur slagoffers en soms ook amnestieaansoekers pastoraal te begelei. Talle vergaderings en werskwinkels om die versoeningsproses te stimuleer, is deur die kerke gereël. 'n Mens kan jou die proses feitlik nie sonder die bydrae van die kerke voorstel nie, het aartsbiskop Tutu dikwels gesê. Wat wel óók waar is, is dat sommige persone - binne én buite die WVK - van mening was dat die kerke se bydrae te groot was, dat die proses te "godsdienstig" verloop het (Meiring, 2000:123-133). Vir die groot meerderheid Suid-Afrikaners was die rol wat die kerke gespeel het, egter vanselfsprekend en ook gewaardeerd. Dat van die kerke verwag sou word om ook by die verdere verloop van die proses die implementeringsfase - $n$ rol te speel, was ewe vanselfsprekend (Connor 1998:115-118). 
Wat meer is, tydens die spesiale sitting van die WVK vir die Geloofsgemeenskappe in die land (Oos-Londen, 17-19 November 1997) het nie net die groot ekumeniese liggame nie, maar feitlik alle kerkgenootskappe in Suid-Afrika, hulle erntsig daartoe verbind om wat die versoeningsproses en die reparasieproses betref, hul deel te doen. In die voorleggings van die verskillende kerke is praktiese voorstelle gemaak oor hoe en waar die kerke betrokke sou kon raak. Ook die verteenwoordigers van dic Moslem-, Hindoe-, Boeddhiste- en Joodse gemeenskappe het hulself in sterk bewoorde verklarings tot die saak verbind (TRC Report Vol IV, 1998:59-92; Meiring 1999:273-294).

Aanvanklik het daar nie soveel van die geloofsgemeenskappe se reparasie-inisiatiewe tereg gekom nie. Dit was asof die kerke en die ander gemeenskappe - soos die res van die land - na die lang en dikwels pynlik WVK-proses eers weer hul spreekwoordelike asems moes terugkry. Teen die middel van 1999 het een kerklike vergadering na die ander egter weer aandag aan dié sake begin gee. Toe die protesstemme van slagoffers en oud-WVK-lede sedert die begin van 2000 oor die stadige vordering wat daar met die reparasieproses gemaak is begin opklink het, het talle kerkleiers sáámgepraat.

Wat staan die kerke ten opsigte van die reparasieproses te doen? Waar sou hulle 'n eie bydrae kon lewer? 'n Drievoudige uitdaging wag op die kerke en ander geloofsgemeenskappe.

\section{2 'n Profetiese stem}

In die verlede het die kerke dikwels die vrymoedigheid geneem om waar onreg gepleeg is, waar mense gely het, ' $n$ ernstige woord te spreek. Dit hoort tot die opdrag wat die Here van die kerk aan sy volgelinge gegee het, dat hulle vir reg en geregtigheid sal staan, dat hulle hul met oortuiging aan die kant van die verdruktes en verontregtes sal skaar. Soos die kerke in die apartheidsjare die destydse regering dikwels oor die verontregting van miljoene mede-Suid-Afrikaners voor stok gekry het, het die tyd aangebreek dat ook die huidige regering oor hul versuim om hul beloftes gestand te doen, om die reparasievoorstelle te begin implementer, aangespreek behoort te word. Desmond Tutu se opvolger as aartsbiskop van Kaapstad, Njongonkulu Ndungane, was een van die weinige kerkleiers wat die afgelope tyd sy stem - met baie sterk woorde - by dié van Tutu, Sooka, en die ander gevoeg het. Die regering se prioriteite moet ernstig bevraagteken word, het hy betoog. Om te sê dat die regering nie die nodige geld beskikbaar het nie, is ' $n$ onaanvaarbare verskoning, komende van ' $n$ regering wat sopas R30 biljoen vir wapenaankope opsy gesit het (The Star, 29 May 2000:13).

Baie meer stemme is egter nodig. ' $n$ Mens kan met reg verwag dat die kerklike gemeenskap ' $n$ profetiese stem sal laat hoor. Ter wille van die slagoffers wat gevaar loop om ernstige onreg te ly, sal die kerke dit moet 
doen. Maar ook ter wille van die breë Suid-Afrikaanse samelewing durf hulle nie stilbly nie. Sonder dat mense sien en ervaar dat reg en geregtigheid in die land seëvier, sal enige versoeningsproses moeilik van die grond af kom. Restitusie in een of ander vorm is ' $n$ belangrike voorvereiste vir versoening. As dit waar is wat Sooka en ander kommentators beweer dat die versuim om ' $n$ behoorlike reparasieproses aan die gang te kry, SuidAfrika in die toekoms in ' $n$ Zimbabwe-situasie sal kan beland - waar oudstryders die reg in eie hande geneem en blanke plase as reparasie vir onregte van die verlede beset het, het die kerke ' $n$ morele verantwoordelikheid om hard en duidelik te práát.

\subsection{Steun aan die reparasiefonds}

In die beredenering van die kontantuitbetalings wat aan slagoffers gemaak moet word (die "individual reparations grant" waarna in par 4.2 hierbo verwys is) het die kerke ' $n$ groot belang gehad. Hulle wou immers toesien dat die slagoffers en hul gesinne inderdaad by die proses baat. Aan die werkswinkels wat gehou is om die teikenbedrag vir reparasie-uitbetalings te bepaal, het verskeie kerke en kerklike diensorganisasies deelgeneem. Terwyl die WVK-voorstel gelui het dat die regering self in die eerste plek die verantwoordelikheid moes aanvaar om die geld te vind en dit deur middel van die spesiale fonds ("President's Fund") te administreer, was die duidelike verwagting gestel dat daar ook bydraes van ander instansies sou kom: van skenkersorganisasies plaaslik sowel as van oorsee. Bo alles is gehoop dat die algemene publiek - mans, vroue en kinders - hulle so met die waarheids- en versoeningsproses sou vereenselwig dat hulle vrywillig en met vreugde sou bydra tot die fonds.

Hier moet die kerke hulle plig nakom en ' $n$ voorbeeld stel, het pastoor Ray McCauley, hoof van die Rhema Bible Church - een van die groot charismatiese kerke in ons land - tydens die die sitting vir geloofsgemeenskappe (Oos-Londen, 17-19 November 1997) verklaar.

"Die skuld van baie Suid-Afrikaanse Christene is tweemaal so groot omdat die apartheidswette en die geweld van die veiligheidswette asook die optrede van die Polisie... teen mede-Christene gemik was... Daar's skaars ' $n$ witmens in Suid-Afrika wat nie deur apartheid bevoordeel is nie. Ons almal, sakelui én die gewone persoon, het die dure plig om bydraes te makk om die slagoffers te help" (Meiring, 1999:285).

' $n$ Interessante voorstel wat die WVK in sy verslag aan die godsdiensgemeenskappe in die land gestel het, voer die saak nog verder: "The Commission recommends that religious communities consider creating a general fund, to be financed in proportion to their resources, that can be used for the victims of past abuses" (TRC Report Vol V,1998:316). Terwyl 
die reparasiedebat maandelank in die pers gevoer is en terwyl die besigheidswêreld soos ook talle ander belangegroepe oor hul bydrae tot die fonds gekonfereer het - en terwyl voorstanders en teenstanders van die instelling van "n Reparasie-belasting ("reparation tax") hewig van mekaar verskil het - was die algemene gevoel: meer as enige van die ander groepe behoort die kerke hier in staat te wees om ' $n$ voorbeeld te stel en ' $n$ eie bydae te lewer. Watter besondere boodskap sou dit nie vir die slagoffers en hulle gesinne - ook vir die hele samelewing - inhou nie?

\subsection{Laat die kerke dié dinge doen wat hulle goed kan doen.}

In 'n aantal onderafdelings van die WVK-voorstelle word daar na 'n die spesiale terreine waar die geloofsgemeenskappe - beter as enige ander groep - spesifieke bydraes ten opsigte van reparasie kan maak, verwys (TRC Report v, pp 316-318).

- Simboliese reparasie: Wat versoeningsaksies betref, het die kerke 'n lang ervaring wat oor jare verwerf is. Sou die kerke - en ook die ander geloofsgemeenskappe - op die gebied in die jare wat kom ' $n$ rol wou speel - nie net deur die organiseer van plaaslike en ook nasionale versoeningsaksies nie, maar ook deur die opstel van spesiale liturgieë vir hierdie geleenthede, liturgieë waarby mense van alle bevolkingsgroepe en kultuurgroepe hulleself tuis sou vind? Die kerke in Suid-Afrika wat dit reggekry het om verteenwoordigers - van verskillende bevolkingsgroepe en kultuurgroepe in een gemeenskap saam te snoer, is besonder goed geplaas om wat simboliese reparasie betref, ' $n$ voorbeeld te stel.

- Gemeenskapsreparasie: Op die terreine van onderwys, gesondheidsdienste en gemeenskapsontwikkeling het die geloofsgemeenskappe deur die jare ' $n$ spesiale bydrae gelewer - en waardevolle kennis en ervaring opgedoen. Sou die kerke - wat gedurende die apartheidsjare om ' $n$ verskeidenheid van redes sekere van hierdie verantwoordelikhede prysgegee het, wat soms gedwing was om dit prys te gee - nuwe inisiatiewe kon ontwikkel? Opleiding, vaardigheidsontwikke-ling, en die vestiging van trauma-klinieke in agtergeblewe gebiede, word spesifiek in die reparasievoorstelle genoem as terreine waar die kerke leiding sal kan neem. Hul potensiële bydrae tot nasiebou, is volgens die WVK-verslag besonder groot.

- Die herverdeling van bates: Een van die interessante uitdagings wat aan die kerke en ander geloofsgemeenskappe gestel word, vra dat hulle ' $n$ voorbeeld vir die land sal stel wat die herverdeling van materiële besittings betref. Sou die kerke wat lidmate van verskil-lende gemeenskappe en agtergronde - ryk én arm, bevoorreg én agtergeblewe - omvat, sáám kan besluit oor die beste aanwending van geld, geboue en grond? Daar word voorgestel dat die geloofsge-meenskappe ' $n$ lys 
van hul besittings opstel ("n sogenaamde "land audit" onderneem) om te bepaal watter grond hulle aan die armes in die land wat self oor geen grond beskik nie, beskikbaar kan stel. Dit geld veral van grond wat as gevolg van apartheidswetgewing van die verlede in die kerke en ander geloofsgemeenskappe se besit gekom het. Die grond, sê die rapport, behoort aan die oorspronklike eienaars teruggegee te word. Vir talle denominasies wat die afgelope eeue in die land gewerk het - en veral as gevolg van uitgebreide sending-werk heelwat sendingplase en ander eiendomme bekom het - het hierdie versoek van die WVK heelwat stof tot nadenke gegee.

\section{DIE FINALE OORDEEL OOR DIE WAARHEIDS- EN VERSOENINGSKOMMISSIE}

Deur die regering - eintlik die hele Suid-Afrikaanse samelewing - openlik tot verantwoording te roep oor die vertraging van die WVK reparasieprogram, het aartsbiskop Tutu en sy kollegas ' $n$ tydige waarskuwing laat hoor. Uiteindelik kan dit gebeur dat die rol wat die WVK in die geskiedenis van Suid-Afrika gespeel het nie ten eerste aan die werk van die menseregteskendingkomitee gemeet gaan word nie, ook nie aan die moeisame amnestieproses nie, maar aan wat met die reparasieproses gebeur het. Dat ' $n$ lang en uitgebreide verslag oor die apartheidsverlede van die land opgestel is, was belangrik. Dat derduisende slagoffers die geleentheid gekry het om hul verhale ter vertel, was net so waardevol. Dat aan oortreders van alle kante van die politieke spektrum uiteindelik amnestie toegestaan is, het vir duisende amnestieaansoekers en hul gesinne die wèreld beteken, het vir Suid-Afrikaners die ontlonting van ' $n$ potensieel plofbare situasie moontlik gemaak. Maar nadat die hele verhaal vertel is, sal die opperbelangrike vraag oor Suid-Afrika bly hang: Wat het uiteindelik met die slagoffers gebeur? Was die proses vir hulle - die 22400 mans en vroue en kinders wat hul herinnerings van ontsettende lyding en pyn met hul medeburgers gedeel het - die moeite werd? Of is hulle vir die soveelste keer in die steek gelaat?

Die Chileen, José Zalaquett, wat ' $\mathrm{n}$ groot rol in die waarheidskommssie wat in sy land aangestel is gespeel het, het na aanleiding van die ervaring van negentien soortgelyke prosesse wat die afgelope dekades in verskillende lande oor die wêreld afgespeel het, ' $n$ insiggewende opmerking gemaak: Uiteindelik word die sukses van waarheidskommissies aan drie vrae gemeet. Eerstens: het die volk eienaarskap van die proses aanvaar? Tweedens: het die regering van die land wat die kommissie aangestel het, die infrastruktuur verskaf het en uiteindelik ook die verslag ontvang het, die politieke wil om die voorstelle van die kommissie uit te voer? Derdens: om te kan slaag, moet die proses ook kan stop. Het die 
kommissie dit reggekry om die proses tot ' $n$ sinvolle einde te bring? (Meiring 1999:379-380).

Vir die doeleindes van hierdie artikel is Zalaquett se tweede vraag die belangrike: het die regering die wil en die vermoë om die reparasievoorstelle uit te voer?

Soos Yasmin Sooka gesê het: "The silence is deafening!"

\section{Literatuurverwysings}

Coonor, B F 1998. The difficult Traverse. From Amnesty to Reconciliation, Pietermaritzburg: Cluster Publications.

Krog, A 1999. "The TRC and National Unity", in: The Truth and Reconcilation in South Africa and the Netherlands (eds) Robert Dorsman, Hans Hartman en Lieneke Noteboom-Kronemeijer), Utrecht: SIM Special.

Meiring, P G J 1998. Kroniek van die Waarheidskommissie. Op reis deur die verlede en die hede na die toekoms van Suid-Afrika, Vanderbijlpark: Carpe Diem Uitgewers.

Meiring, P G J 2000. "The baruti vs the lawyers: the role of religion in the TRC process", in Looking back. Reaching forward (eds Charles Villa-Vicencio, Wilhelm Verwoerd), Cape Town/London: Zed Books.

Muller-Fahrenholz, G 1997. The Art of Forgiveness, Geneva: WCC Publications Orr, Wendy 2000: "Reparation delayed is healing retarded" in Looking Back. Reaching Forward (eds) Charles Villa-Vicencio, Wilhelm Verwoerd), Cape Town/London: Zed Books.

Sooka, Y 2000. "Re Seke Ralebala. We Should Not Forget", Openbare voordrag Gelewer by die $S A B C$ se bekendstelling van 'n laserskyfreeks oor die werk van die $V K$ (13 April 2000), Johannesburg: SABC.

Truth and Reconciliation Commission 1998. Truth and Reconciliation Commission of South Africa Report (Volumes 1-V), Cape Town: TRC (Juta).

Tutu, D 1999. No Future Without Forgiveness, London/Johannesburg: Rider. 